\title{
Distance Learning Courses: New Opportunities for the Development of University Education
}

\section{Cursos a distancia: nuevas oportunidades para el desarrollo de la educación universitaria}

\author{
Monica-Nataliia Wagner \\ Peoples' Friendship University of Russia, Russia \\ https://orcid.org/0000-0002-0396-867X \\ Milana Kupriyanova \\ Peoples' Friendship University of Russia, Russia \\ https://orcid.org/0000-0002-0654-205X \\ Umeda Ovezova \\ Peoples' Friendship University of Russia, Russia \\ https://orcid.org/0000-0003-2595-3775 \\ Anna Ilina \\ Peoples' Friendship University of Russia, Russia \\ https://orcid.org/0000-00034282-8095
}




\section{Summary}

DL is a new means of implementing the learning process, which is based on the use of modern information and telecommunication technologies that allow studying at a distance without personal contact between the teacher and the student. DL is one of the main ways of computerization and automation of education and the use of the latest technologies in training and serves to increase the effectiveness of education as such. The organization of high-quality distance education will increase educational capacities and positively affect the intellectual potential of the state. This paper discusses the features of distance learning. The authors also describe the basic functional modules of modern distance learning management systems that contain access to educational materials and the means to ensure communication between participants in the distance learning process. According to the formulated modules, the authors perform a review and comparison of the availability and implementation of distance learning modules in such distance learning systems as Moodle, Claronline, ATutor, SharePointLMS, Live@EDU, and eFront.

Keywords: Higher Education, Distance Learning, Distance Learning Courses, Distance Learning System, Distance Learning Course Module.

\section{Resumen}

La DL es una nueva forma de implementar el proceso de aprendizaje, que se basa en el uso de modernas tecnologías de la información y las telecomunicaciones que permiten estudiar a distancia sin contacto personal entre el docente y el alumno. La DL es una de las principales formas de informatización y automatización de la educación y el uso de las últimas tecnologías en la formación y sirve para aumentar la eficacia de la educación como tal. La organización de educación a distancia de alta calidad aumentará las capacidades educativas y afectará positivamente el potencial intelectual del estado. Este artículo analiza las características del aprendizaje a distancia. Los autores también describen los módulos funcionales básicos de los sistemas modernos de gestión de la educación a distancia que contienen acceso a materiales educativos y los medios para asegurar la comunicación entre los participantes en el proceso de educación a distancia. De acuerdo con los módulos formulados, los autores realizan una revisión y comparación de la disponibilidad e implementación de módulos de aprendizaje a distancia en sistemas de aprendizaje a distancia como Moodle, Claronline, ATutor, SharePointLMS, Live @ EDU y eFront.

Palabras clave: educación superior, aprendizaje a distancia, cursos de aprendizaje a distancia, sistema de aprendizaje a distancia, módulo del curso de aprendizaje a distancia.

\section{Introduction}

At present, the possibilities of the Internet keep expanding every day, the computerization of society is growing, and the cost of services is decreasing. This makes it possible to use the latest information and telecommunication technologies in all spheres of life (Duisenova et al., 2020; Ivanova, Sorokina, 2020).

Universities, academies, institutes, i.e. all those higher education institutions that are interested in high-quality training of professionals, have become outposts in introducing 
distance learning (DL) into educational practice as the most promising, humanistic, integral, and individualization-oriented form of the educational process (Gdansky et al., 2020; Soloveva et al., 2020).

A. Sokolov (2006) understands by DL the individualized process of acquiring knowledge, skills, and methods of cognitive activity that occurs during the indirect interaction of DL subjects in a specialized environment created based on modern pedagogical and information and communication technologies. In the process of DL, the participants use remote information products that are sufficient for studying individual subjects.

According to researchers (Aleskovskii et al., 2015), DL is a new educational organization based on the use of the best traditional methods of obtaining knowledge and new information and telecommunication technologies, as well as the principles of self-education. It is intended for the general population regardless of their level of income, place of residence, and state of health.

According to C. Harper et al. (2004), DL allows one to implement interactive technologies for teaching material, receive full higher education, or upgrade one's qualifications and has such advantages as flexibility, relevance, convenience, modularity, economic efficiency, interactivity, and the lack of geographical boundaries for obtaining an education.

According to researchers (Perumalla et al., 2011; Matraeva et al., 2020), due to such means of DL as discussion forums, electronic discussions of learned material, etc., a new learning environment is being created in which students feel like an integral part of the team, which enhances the motivation for learning. In turn, teachers should be familiar with the methods of creating and maintaining this kind of educational environment, develop strategies for active interaction between participants in the educational process, increase students' creative activity, and upgrade their qualifications.

Only a small part of the educational process is taught in the form of theoretical material, i.e. lectures. The main task for a teacher working in the DL format is to orient students towards a creative search for information and the ability to independently acquire the necessary knowledge and apply it in solving practical problems using modern technologies (Baruch et al., 2003).

Besides, with DL, the role and requirements for teachers change. The introduction of new teaching technologies into the educational process significantly increases the teacher's responsibility for the quality of teaching materials, the content of which requires constant updating and improvement, while the experience of the traditional organization of the educational process needs to be adapted to the new communication system between the teacher and the student. The use of automated systems for knowledge control, counseling, and teaching with the help of computer technology can significantly reduce the time spent by the teacher at the stages of knowledge control, relieve students' overstrain and nervousness in the learning process and passing exams, and make the learning process more vivid and attractive. Under such conditions, the teacher acts not only as of the developer of the electronic version of the educational and methodological support of their subject but also as the supervisor of cognitive processes (Rogerson-Revell, 2015; King et al., 2001).

Fast communication with feedback from students is received using the results of testing which not only provides information about the success and level of achievement of each student but also poses new methodological tasks for the teacher. For the vast majority of teachers specializing in subjects not related to information technology, the problem of developing technologies and software tools, as well as the adaptation of traditional educational resources to new technologies, remains demanding (Cinar, Torenli, 2010). 
Students' wide access to educational resources is not limited by the time and distance of the educational institution. There is always the opportunity to work with electronic versions of software and methodological support in one or another subject that forms the appropriate level of the "teacher-student" dialogue for this subject. In this regard, the teacher's new function in creating DL courses is expressed in the search for dialogue that increases learning motivation and contributes to the development of students' cognitive interests (Volery, Lord, 2000).

DL uses two main types of technology. One of them involves direct contact between the teacher and the student (the synchronous method) and the second includes the possibility of indirect contact between the teacher and the student (the asynchronous method) (Pozdnyakov, 2014). The use of these technologies depends primarily on the level of development of Internet technologies in a country or region and, second, on the level of development of information technologies in an educational institution, as well as on the degree of readiness of the teachers to use these technologies, which is, perhaps the most important condition for success (Shevelev, Kuznetsova, 2011).

Asynchronous (indirect) DL can use technologies such as the independent study of educational materials and auxiliary materials (lecture courses, textbooks, manuals that are electronic copies of printed books, as well as electronic textbooks combined into a single educational space) by students or other audience remotely, that is, at home, in the workplace, during free time, on vacation, etc. (Anderson, Dron, 2011). Asynchronous technologies make it possible to carry out intermediate control of knowledge acquired by students using a variety of test tools (tests, written tasks, task books, creative tasks, group projects, etc.).

Indirect asynchronous DL has important advantages. First of all, it is an opportunity for free time planning for the student. A student or listener can begin to study the material at a time convenient for them, distribute the volume of the studied material, etc., at their discretion, but within the time allotted for studying the subject, as the dates of the intermediate and final control of covered topics are set at the start. In this case, it is possible to regularly seek help from a teacher as difficulties arise in the study of subjects. The mode of consulting the teacher can also be selected by the student independently (Heydenrych, Prinsloo, 2010).

Synchronous technologies of direct DL allow establishing direct contact between the teacher and the student in real-time, including visual contact. These technologies are more social, they allow the teacher to conduct a direct survey of students (to control knowledge) and get answers to questions in real-time. Synchronous DL technologies allow conducting video lectures and other types of classes, such as round tables, discussions, consultations, video conferences, etc. in real-time. Synchronous DL technologies allow for more thorough control, including visual control of knowledge, both intermediate and final (such as tests, exams, defense of term papers, abstracts, group projects) when the examiner receives answers immediately. Synchronous DL technologies allow using the possibility of holding strategic games in real-time based on situational modeling centers and carrying out group projects when project participants are located in different geographical locations hundreds of kilometers from each other (Simpson, 2004).

Synchronous direct DL technologies are more consistent with the specifics of obtaining the first higher education, as they allow bringing correspondence courses taught via DL closer to full-time study, exercising closer control of the educational process, and establishing close direct constant contact between teachers and students during the period between the exam sessions.

The paper aims to carry out a comparative analysis of the availability and implementation of DL modules in various DL systems based on an analysis of modern DL systems. 
The study hypothesis states that an extensive range of DL systems allows one to develop various DL courses and opens up new opportunities for the development of university education.

According to the results of the study, we can conclude that the goal set in the study was achieved.

\section{Methods}

Times In the process of our study, we used such research methods as:

- analysis of scientific literature on using DL courses as new opportunities for the development of university education;

- an expert survey to determine the basic functionalities that modern DL systems should provide when creating DL courses;

- a comparative analysis based on an expert survey of the availability and implementation of DL modules in various DL systems.

The online expert survey included answers given by 50 experts, teachers, and university staff who participated in the development of DL courses in the DL system.

\section{Results}

Times Based on an expert survey, it was determined that DL systems consisted of a large number of interconnected modules. Moreover, the experts who participated in the survey identified the main functionalities that modern DL systems should provide when creating DL courses (Table 1).

Table (1): The main functionality of modern DL systems

\begin{tabular}{|c|c|c|c|}
\hline No. & $\begin{array}{|lll|}\begin{array}{l}\text { Functionality of } \\
\text { systems }\end{array} & \text { DL } \\
\end{array}$ & Requirements & $\% *$ \\
\hline 1 & $\begin{array}{l}\text { Access to educational } \\
\text { content }\end{array}$ & $\begin{array}{l}\text { The system needs to provide the ability to } \\
\text { authorize the user, manage the rights of user } \\
\text { groups, and control access to training materials }\end{array}$ & $90 \%$ \\
\hline 2 & $\begin{array}{l}\text { Providing convenient } \\
\text { administration tools }\end{array}$ & $\begin{array}{l}\text { A typical set of functionalities includes is user } \\
\text { registration, management of user groups, } \\
\text { management of distance courses and control } \\
\text { measures, etc. }\end{array}$ & $85 \%$ \\
\hline 3 & $\begin{array}{l}\text { Providing communication } \\
\text { tools between course users }\end{array}$ & $\begin{array}{l}\text { Today, there are many opportunities for } \\
\text { communication. The main ones include video } \\
\text { and audio conferences, forums, chats, blogs, } \\
\text { email, etc. }\end{array}$ & $80 \%$ \\
\hline 4 & $\begin{array}{l}\text { Ability to create curricula } \\
\text { using competency } \\
\text { management models }\end{array}$ & $\begin{array}{l}\text { For the distribution of curricula, models are } \\
\text { built that indicate the role that the user } \\
\text { performs and a set of their capabilities } \\
\text { (competencies). In the future, for each } \\
\text { competency, there should be a set of courses } \\
\text { that need to be studied and a set of control } \\
\text { measures that need to be implemented. Based } \\
\text { on the constructed models, the system creates } \\
\text { appropriate curricula for each user }\end{array}$ & $75 \%$ \\
\hline & Report generation & $\begin{array}{l}\text { Providing the ability to generate reports at the } \\
\text { request of the user }\end{array}$ & $75 \%$ \\
\hline
\end{tabular}


Integration Integration with various information systems

$70 \%$

Note: compiled based on the expert survey; *percentage of expert references

Given the necessary functional capabilities of the DL systems indicated by the interviewed experts, it is possible to synthesize the following modules of distance courses: in the system;

- the module for developing distance courses and presenting educational information

- the test development and support module;

- the control module of the lecture material and user activity;

- independent work;

- the module for interactive communication between course users: the teacher with students, students between themselves, students with the teacher.

Let us compare the availability and implementation of DL course modules in various DL systems (Tables 2-6).

Table (2): Module for the development of distance courses and the presentation of educational information

\begin{tabular}{|c|c|}
\hline System & Claroline \\
\hline $\begin{array}{l}\text { Module } \\
\text { implementation }\end{array}$ &  \\
\hline System & Live@EDU \\
\hline Module implementation & $\begin{array}{l}\text { 10. The Lectures module makes it } 13 \text {. The Lesson module allows } \\
\text { possible to introduce a course building a logical structure of } \\
\text { textbook, i.e. a separate HTMLlecture materials } \\
\text { document that consists of many } \\
\text { pages and files, into the system } \\
\text { 11. The Methodological materials } \\
\text { module lets the teacher upload } \\
\text { materials for the course and provides } \\
\text { access to them for the student } \\
\text { 12. The Bibliography module }\end{array}$ \\
\hline System & SharePointLMS \\
\hline $\begin{array}{l}\text { Module } \\
\text { implementation }\end{array}$ & $\begin{array}{l}\text { 14. The Lesson module for the } 16 \text {. The Document library } \\
\text { presentation of educational material module creates a single } \\
\text { 15. The Glossary module adds centralized point of storage for } \\
\text { comments to definitions and educational materials } \\
\text { automatically links words in lectures } \\
\text { on glossary definitions }\end{array}$ \\
\hline
\end{tabular}

Note: compiled based on the expert survey

Table (3): Test development and support module

\begin{tabular}{l|l|l}
\hline System & ATutor & Claroline
\end{tabular}




\begin{tabular}{|c|c|}
\hline \begin{tabular}{|l|} 
Module \\
implementation
\end{tabular} &  \\
\hline System & Live@EDU \\
\hline $\begin{array}{l}\text { Module } \\
\text { implementation }\end{array}$ & $\begin{array}{l}\text { 3. The Grades module provides an } 5 \text {. The Tests module lets the } \\
\text { opportunity for a teacher to enter teacher create new tests and } \\
\text { grades for specific tasks } \\
\text { provides information on the } \\
\text { 4. The Tests module lets the teacher performance of tasks by users } \\
\text { easily create tests that students can } \\
\text { fill out on the WWW pages } \\
\text { module allows to view statistics } \\
\text { of correct and incorrect answers } \\
\text { to the questions included in the } \\
\text { tests }\end{array}$ \\
\hline System & SharePointLMS \\
\hline $\begin{array}{l}\text { Module } \\
\text { implementation }\end{array}$ & $\begin{array}{l}\text { 7. The Test module consists of two } 8 \text {. The Tests module is designed } \\
\text { parts: the test itself and a question to create tests or surveys and } \\
\text { database. The test consists of various } \\
\text { questions selected from the question } \\
\text { database. The question database } \\
\text { consists of different types of } \\
\text { questions: with one correct answer, } \\
\text { many possible correct answer } \\
\text { options, or the ability to enter one's } \\
\text { option }\end{array}$ \\
\hline
\end{tabular}

Note: compiled based on the expert survey

Table (4): Monitoring lecture material and user activity

\begin{tabular}{|c|c|c|}
\hline System & ATutor & Claroline \\
\hline Module implementation & $\begin{array}{l}\text { 1. Survey of participants in the course } \\
\text { (with no grades) } \\
\text { 2. Statistics }\end{array}$ & $\begin{array}{l}\text { 3. Online exercises with a list of } \\
\text { questions } \\
\text { 4. Statistics } \\
\text { 5. Choosing a learning scenario }\end{array}$ \\
\hline System & Live@EDU & eFront \\
\hline Module implementation & $\begin{array}{l}\text { 6. Task } \\
\text { 7. Task folders }\end{array}$ & $\begin{array}{l}\text { 8. Reports for each user (tabs: } \\
\text { Lessons, Courses, More } \\
\text { information) } \\
\text { 9. Lesson reports: The Question } \\
\text { tab provides information on } \\
\text { student answers to the tests in a } \\
\text { particular lesson } \\
\text { 10. The Activity tab is a student } \\
\text { activity report for a specified } \\
\text { period }\end{array}$ \\
\hline System & Moodle & SharePointLMS \\
\hline Module implementation & $\begin{array}{l}\text { 11. The journal of user (student) } \\
\text { activity registration in the } \\
\text { Management block. Possible log } \\
\text { filtering options include day, course } \\
\text { name, group, participant, completed } \\
\text { task }\end{array}$ & $\begin{array}{l}\text { 12. The Curriculum module is } \\
\text { designed to create an orderly } \\
\text { structure for the presentation of } \\
\text { educational materials, as well as } \\
\text { the creation of a system for } \\
\text { testing and monitoring student } \\
\text { performance of the course } \\
\text { 13. The Attendance module is } \\
\text { designed to register student } \\
\text { attendance during the course } \\
\text { 14. Progress report. The module } \\
\text { saves all information about }\end{array}$ \\
\hline
\end{tabular}




\section{student performance}

Note: compiled based on the expert survey

Table (5): Independent work

\begin{tabular}{|c|c|}
\hline System & 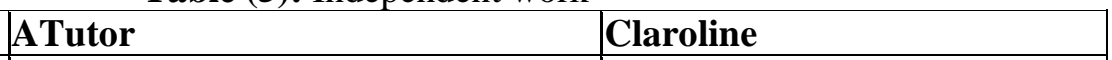 \\
\hline Module implementation & $\begin{array}{l}\text { 1. Tasks (the instructor sets the name, } \\
\text { essence, and performer) } \\
\begin{array}{l}\text { 3. Performing tasks according to } \\
\text { the selected scenario (name, } \\
\text { page or menu tab }\end{array} \\
\begin{array}{l}\text { description, typer } \\
\text { visibility, download permission) }\end{array}\end{array}$ \\
\hline System & Live@EDU \\
\hline Module implementation & $\begin{array}{l}\text { 4. The Workspace module provides a } \begin{array}{l}5 . \text { The Projects tab of the } \\
\text { common space on the server, which } \\
\text { meports module provides } \\
\text { makes } \\
\text { information on students } \\
\text { implementation of projects }\end{array} \\
\end{array}$ \\
\hline System & SharePointLMS \\
\hline Module implementation &  \\
\hline
\end{tabular}

Note: compiled based on the expert survey

Table (6): Interactive communication

\begin{tabular}{|c|c|c|c|c|}
\hline \multirow[t]{2}{*}{ No. } & \multirow[t]{2}{*}{ System } & \multicolumn{3}{|c|}{ Interactive communication } \\
\hline & & Students with students & The teacher w & $\begin{array}{l}\text { Students with the } \\
\text { teacher }\end{array}$ \\
\hline 1 & ATutor & $\begin{array}{l}\text { ges, file } \\
\text {, forum }\end{array}$ & $\begin{array}{l}\text { ts, FAQ, chat, } \\
\text { on a banner, } \\
\text { ages, RSS feed }\end{array}$ & $\begin{array}{l}\text { 1. Forum, chat, } \\
\text { personal messages, } \\
\text { survey }\end{array}$ \\
\hline 2 & e & $\begin{array}{lr}\text { Chat, } & \text { forum, } \\
\text { announcement, } & \\
\text { calendar } & \text { event } \\
\text { creation, Wiki } & \\
\end{array}$ & $\begin{array}{l}\text { Announceme } \\
\text { forum, Wiki, } \\
\text { events }\end{array}$ & $\begin{array}{l}\text { Forum, chat, } \\
\text { announcement, } \\
\text { calendar events }\end{array}$ \\
\hline 3 & $\bar{U}$ & WWW & $\mathrm{AQ}^{\mathrm{c}}$ & $\mathrm{C}$ \\
\hline 4 & eFront & $\begin{array}{l}\text { Forum, chat, personal } \\
\text { messages, the ability to } \\
\text { install blog modules } \\
\text { and wiki }\end{array}$ & $\begin{array}{l}\text { Forum, chat, personal } \\
\text { messages, blog, message } \\
\text { board, FAQ, quote of the } \\
\text { day, general comments }\end{array}$ & $\begin{array}{l}\text { Forum, chat, } \\
\text { comments, private } \\
\text { messages }\end{array}$ \\
\hline 5 & Moodle & $\begin{array}{l}\text { Forum, } \\
\text { messaging }\end{array}$ & Forum, chat, messaging & Chat, messaging \\
\hline 6 & $\begin{array}{l}\text { SharePoint } \\
\text { LMS }\end{array}$ & $\begin{array}{l}\text { Personal messages, } \\
\text { forum, chat }\end{array}$ & $\begin{array}{l}\text { Conferences, personal } \\
\text { messages, RSS feed, forum }\end{array}$ & $\begin{array}{l}\text { Forum, } \\
\text { messages }\end{array}$ \\
\hline
\end{tabular}

Note: compiled based on the expert survey 


\section{Discussion}

Today, a wide range of DL systems and DL management systems is widely used, including both open-source (shareware) and paid systems, designed for the general public or a highly specific audience.

Let us review the systems analyzed in more detail.

ATutor is a modular open-source learning management system. It is distributed under the GNU General Public License. To install, the user must have a computer with the Apache 1.3.x web server, PHP versions> 4.2.0, and MySQL versions> 3.23.x and> 4.0.12 (versions 4.1.x and 5.x are not officially supported). The system was designed considering the availability and adaptability at the request of the user. There are no restrictions regarding the server's operating system, as the system is cross-platform (Vucic, 2002).

Claroline is an open-source e-business and electronic activity platform. Similarly to ATutor, it is distributed under the GNU General Public License. It is compatible with operating systems such as Linux, Mac, and Windows. It provides an intuitive interface for administration. Claroline LMS is based on the concept of spaces associated with a course or teaching activity. Each space is equipped with tools for creating, organizing, and managing educational materials, opportunities for ensuring interaction between users, etc. (Lebrun et al., 2009).

Live@EDU is a DL system made using Active Server Pages technology on the Microsoft platform. For installation and correct operation of the system, the server part must be provided with Microsoft Windows NT Server 4.0, Microsoft SQL Server 7.0, and Microsoft Internet Information Server 4.0. The client part must have an installed OS that provides access to the Internet and a browser that supports the HTTP protocol version 3.0, as well as software for viewing and creating lecture materials (Live@EDU Outline Handout, n.d).

eFront is an e-learning system that combines the functions of learning management systems, the creation, and management of training materials. The system includes three types of users: the Administrator, the Teacher, and the Student (Dmitriev, 2015).

Moodle is an open-source modular software package designed to create DL courses and web sites. This DL management program is focused on the interaction between teachers and students and is also used to support full-time courses. Moodle can be installed on any computer that supports PHP and work with MySQL, PostgreSQL, Microsoft SQL Server; cross-platform software (Tund, Tarasenko, 2013).

SharePointLMS is a DL system developed on the multifunctional platform MS Office SharePoint Server 2007. It is a comprehensive solution that brings together all users (teachers, students, administrators, etc.) into united information and educational space and provides tools for collaboration. Unlike Moodle, Claroline, and ATutor, the system is distributed for a fee. It is used not only by educational institutions and training centers but also by enterprises, organizations, and state structures (SharePointLMS. Versiya 3.0.: n.d).

As a brief analysis of DL systems showed, modern information and computer technologies are developing very quickly. However, according to one of the interviewed experts at a higher education institution, there is no single system of information and software environment: "In most cases, computer software is developed directly for a particular subject and in a particular educational institution. As a rule, this is a combination of software, text, methodological, test, audio and video accompaniment, which practically duplicates information and sections of textbooks and previous teaching materials". 
The experts who participated in the survey formulated the basic requirements for the effective creation of DL resources:

1. Providing special measures to prepare students of DL courses for educational activities in a specific network of educational environments;

2. Preparing staff capable of creating DL resources and expertly accompany the learning process;

3. Based on a systematic approach and the features of the DL process, developing principles that relate to the means, forms, training methods, and activities of educational participants in a networked educational environment.

According to the majority of the experts interviewed (85\%), for the teaching process to be as effective as possible, it must be properly organized using a system of mandatory organizational measures. First, it is necessary to establish the level of basic knowledge of the subject for each student (entrance control) and learn more about them, i.e. their interests, needs, and values. Second, considering the goals and objectives of the subject, as well as the results of the analysis of information on the value-based orientations of students, obtained at the previous organizational stage, the teacher needs to form a package of educational and methodological support for students in electronic form. Third, to familiarize students with the available teaching materials, one must provide recommendations on the organization and methods of working with various components of this package, as well as specific information on access to other sites, the contents of which will be useful for independent educational and cognitive work. Besides, it is necessary to inform the students of the planned control measures, explain in what form they will be carried out, and provide criteria for assessing knowledge.

\section{Conclusion}

DL opens up new opportunities for the development of education at the university, which are manifested in the possibility of introducing the latest pedagogical, psychological, and methodological developments with the breakdown of distance course material into separate functionally completed modules (topics), which are studied as they are acquired and correspond to the abilities of an individual student or group as a whole.

The results of the study confirmed the hypothesis that an extensive range of DL systems allows for the development of various distance courses and opens up new opportunities for the development of university education.

\section{References}

Aleskovskii, V.V., Pavlova, T.A., Yanovskii, V.V. (2015). Kontseptsiya distantsionnogo obucheniya $v$ vuze - proektnaya organizatsiya i upravlenie [The concept of distance learning at the level of tertiary education: design organization and management]. Upravlencheskoe konsultirovanie, 2: 99-106.

Anderson, T., Dron, J. (2011). Three generations of distance education pedagogy. International Review of Research in Open and Distance Learning, 12(3): 80-97.

Baruch, O., Barth, J., Lev, Y., Shetinbok, A. (2003). Teacher - student interactions and learning outcomes in a distance learning environment. Internet and Higher Education, 6: 65-75.

Cinar, M., Torenli, N. (2010). Redesign online courses with students' expectations: a case study with a new infrastructure. Social and Behavioural Science, 9: 2013-2016.

Dmitriev, D.S. (2015). Sistema elektronnogo obucheniya EFront: ucheb. posobie [EFront elearning system: a manual]. Samara: Izd-vo "Samarskii universitet". 
Duisenova, S.M., Kylyshbaeva, B.N., Avsydykova, K.A., Ishanov, Ye.Kh. (2020). Sociological Analysis of Educational Strategies in the System of Higher Education in Kazakhstan. Space and Culture, India, 7(4): 181-193.

Gdansky, N.I., Kulikova, N.L., Budnik, A.A., Sokolov, I.V. (2020). Stem Technology in the Study Of Educational Robotics. Revista Inclusiones, 7: 206-219.

Harper, C.H., Chen, K., Yen, D.C. (2004). Distance learning, virtual classrooms, and teaching pedagogy in the Internet environment. Technology in Society, 26: 585-598.

Heydenrych, J.F., Prinsloo, P. (2010). Revisiting the five generations of distance education: Quo vadis? Progressio, 32(1): 5-26.

Ivanova, N.V., Sorokina, T.M. (2020). The Relationship between the Categories "Educational Environment" and "Educational Space" in Russian Psychological and Pedagogical Science. Revista Inclusiones, 7: 100-118.

King, F.B., Young, M.F., Drivere-Richmond, K., Schrader, P.G. (2001). Defining distance learning and distance education. Association for the Advancement of Computing in Education, 9(1): 1-14.

Lebrun, M., Docq, F., Smidts, D. (2009). Claroline, an Internet Teaching and Learning Platform to Foster Teachers' Professional Development and Improve Teaching Quality: First Approaches. Association for the Advancement of Computing in Education, 17(4): 347-362.

Live@EDU Outline Handout. (n.d). Available: https://www.imperial.edu/docs/informationtechnology/support-training/training-handouts/806-live-edu-outline-handout/file

Matraeva, A.D., Rybakova, M.V., Vinichenko, M.V., Oseev, A.A., Ljapunova, N.V. (2020). Development of Creativity of Students in Higher Educational Institutions: Assessment of Students and Experts. Universal Journal of Educational Research, 8(1): 8-16.

Perumalla, C., Mak, J., Kee, N., Maththews, S. (2011). Integrating web applications to provide an effective distance online learning environment for students. Computer Science, 3: 770-784.

Pozdnyakov, V.A. (2014). Elektronnoe obuchenie v sovremennykh usloviyakh: tseli i tekhnologii [E-learning in modern conditions: goals and technologies]. Obrazovanie v sovremennom mire: sbornik nauchnykh statei [Education in the modern world: a collection of scientific articles], 9: 87-94.

Rogerson-Revell, P. (2015). Constructively aligning technologies with learning and assessment in a distance education master's programme. Distance Education, 36(1): 129-147.

SharePointLMS. Versiya 3.0. (n.d). Sistema distantsionnogo obucheniya. Rukovodstvo polzovatelya. Sovmestnoe reshenie dlya distantsionnogo obrazovaniya na osnovanii evropeiskogo opyta [SharePointLMS. Version 3.0 Distance learning system. User manual. Joint solution for distance education based on European experience]. Available:

http://www.lms.eduportal44.ru/cdo/SiteAssets/SitePages/Инструкция/Руководство \%20пользователя\%20SharePointLMS\%203.0.pdf

SHEVELEV, N.A., KUZNETSOVA, T.A. (2011). Organizatsiya obrazovatelnoi sredy vuza na osnove sistemy distantsionnogo obucheniya. [Organization of the educational environment of a university based on a distance learning system]. Vysshee obrazovanie v Rossii, 7: 88-93.

Simpson, O. (2004). The impact on retention of interventions to support distance learning students. European Journal of Open, Distance and E-Learning, 19: 79-95.

Soloveva, S., Miniakhmetova, O., Kivileva, A., Gitman, Ye. (2020). Integrative Processes of Different Levels in Secondary Vocational Education. Universal Journal of Educational Research, 8(1), 134-142.

Solovov, A. (2006). Distantsionnoe obuchenie: tekhnologii i tselevye gruppy [Distance learning: technologies and target groups]. Vysshee obrazovanie v Rossii, 7: 119-125.

Tund, V.A., Tarasenko, F.P. (2013). Dokumentatsiya po Moodle 2.5. Ch. 1-4 [Documents on Moodle 2.5. Parts 1-4]. Tomsk: TGU. 
Volery, T., Lord, D. (2000). Critical success factors in online education. International Journal of Educational Management, 14(5): 216-223.

Vucic, V. (2002). A Tutor Getting Started. An Overview of interface and functionality. SELF - Science, Education and Learning Freedom. Available: http://eprints.rclis.org/9434/1/atutor-getting-started-final-3-1.pdf 